\title{
Assessment of Sustainability Challenges of FM Radio Stations in Bungoma County, Kenya
}

\author{
Jared M. Mudanya*, Dr. Peres Wenje \\ Masinde Muliro University of Science and Technology, Kakamega Kenya
}

*Corresponding Author: Jared M. Mudanya, Masinde Muliro University of Science and Technology, Kakamega Kenya

\begin{abstract}
Liberalization of airwaves in Kenya has seen the broadcast media growth in leaps and bounds as the number of radio stations outlets has multiplied significantly. This brought with it a cut throat competition among the licensed FM radio stations. They had to innovate survival tactics to become relevant. These radio stations grapple with challenges that threaten their survival among them difficulty in developing programmes that would gratify the audience's expectations and resource deficiency. For survival and the need to find alternative means of income generation, these radio stations have turned into other ways of generating revenue.The objectives of this study were to assess the challenges of sustainability of FM Radio stations explain the resource deficiency in sustainability of FM Radio stations and to find out if advances in technology plays a role in sustainability of FM stations in Bungoma County, Kenya. This study adopted a Mixed-methods research design. The mixed methods is seen in sampling process and the data collection stage. The methodology was employed in collecting, analyzing, and mixing both quantitative and qualitative data in a single study or series of studies whose central premise is that the use of quantitative and qualitative approaches, in combination, provides a better understanding of research problems than either approach alone. Findings of this study reveal that motivation and training of staff, coupled with creation of quality educative and informative content by FM radio stations based on current audience research data or survey, will enhance sustainability of these FM radio stations operating in Bungoma County, Kenya.
\end{abstract}

Keywords: Liberalization, sustainability, airwaves, frequency spectrum.

\section{INTRODUCTION}

Liberalization of broadcasting has had profound effect in Nairobi, but outside the main urban centres, state-run Kenya Broadcasting Corporation provides the only domestic radio and TV for many listeners and viewers, with the rest of FM radio stations still struggling to go further upcountry. The broadcast media, partly as a result of the liberalisation policies, has grown in leaps and bounds as the number of radio and television outlets has multiplied significantly (Githaiga, 2011).

(Mbuba, 2015). Most of these rapidly increasing FM Radio stations suffer from income deficiency because they compete for common potential advertisers and sponsors who prefer to work with established radio stations. For survival and the need to find alternative means of income generations, these radio stations have turned other ways of generating revenue such as SMS premium rate services in conjunction with the mobile telephone service providers, parallel businesses such as Internet services and marketing

\section{Methodology}

This study adopted a Mixed-methods research design. The mixed methods is seen in sampling process and the data collection stage. The methodology was employed in collecting, analyzing, and mixing both quantitative and qualitative data in a single study or series of studies. Its central premise is that the use of quantitative and qualitative approaches, in combination, provides a better understanding of research problems than either approach alone (Creswell \& Plano Clark, 2007).

\section{STUDY AREA}

The study was carried out in Bungoma County, Kenya. Bungoma County is located in the former Western province. It is host to majority of the radio stations licensed to operate in the former western 
Province, Kenya. This study selected five FM Radio stations which include; Nyota FM, Radio Mambo, West FM, Biikap Koreet FM, and Mukwano FM.

Bungoma County is one of the four counties in the former Western Province of Kenya. It has a population of 1,375,063 (Census report, 2009) covering on an area of 2,069 $\mathrm{km}^{2}$. Agriculture is the backbone of Bungoma County and most families rely on crop production and animal rearing. The economy of Bungoma County is mainly agricultural, focusing on the sugarcane and maize industries. The area experiences high rainfall throughout the year, and is home to several large rivers, which are used for small-scale irrigation.

\section{TARGET POPULATION}

The population for this study consisted of personnel working in selected radio stations in Bungoma County. The respondents were drawn from key departments within selected FM radio including; management, programme producers/presenters, technical crew, as well as the marketing \& advertising department. Anselemo, (2014) discerns that a population is a collective term used to describe the total quantity of things (or cases) of the type which is subject to the study. It is also a group of all possible objects of investigation in a given domain, (Calder, 1998). Study population was then categorized and each was purposefully identified as follows. Respondents from the radio sampled FM radio stations included; the station's manager, marketing personnel, technical crew, and finally, producers/presenters. Table 1 below shows the distribution of the target population

Table1: Study Population

\begin{tabular}{|l|l|}
\hline Name of FM radio Station & Specific Respondents in all the stations \\
\hline Nyota FM & Radio Managers \\
\cline { 1 - 1 } Radio Mambo & Marketing Personnel \\
West FM & Technical Personnel \\
Biikap Koret FM & Producers/Presenters \\
\hline Radio Mukwano &
\end{tabular}

\subsection{Sampling Procedure and Sample Size}

Purposive is the main method that was used in getting the sample size. A purposive sample is a nonprobability sample selected based on characteristics of a population and the objective of the study. It is also referred to as judgemental, selective or subjective sampling. This type of sampling can be very useful in situations when you need to reach a target quickly and where sampling for proportionality is not the main concern. (Crossman, 2017)

Specific radio staff were identified to volunteer information useful for the study. By default, the participants from each category of the population bear similarities in the characteristics that differentiate them form others in a particular radio station. This thus yields homogeneity in the targeted respondents from each of the identified groups. For this case therefore, a homogeneous purposive sample is created based on the occupation of the respondents. The sampling procedure is explained as follows.

As indicated above, purposive sampling was employed in order to arrive at the sample size for each category of the study population. According to Denscombe, (2007), a third of the study of population is always representative for sample. With this authorization therefore, the researcher took one third of each category from the target population. This formed the actual size of informants who participated in completing the questionnaires and interview schedule questions. The sample size is shown in table 3.2 below:

Table2: Sample Size

\begin{tabular}{|l|l|l|l|}
\hline $\begin{array}{l}\text { Name of FM radio } \\
\text { Station }\end{array}$ & Sample respondents & \multirow{2}{*}{ Sample size } \\
\hline Nyota FM & Radio Managers & \multicolumn{1}{|c|}{} \\
\cline { 2 - 3 } & Technical Personnel & 1 \\
\cline { 2 - 3 } & Producers/Presenters & 4 \\
\cline { 2 - 3 } & Marketing Personnel & 4 \\
\hline Radio Mambo & Radio Managers & 3 & \\
\cline { 2 - 3 } & Technical Personnel & 1 & \\
\cline { 2 - 3 } & Producers/Presenters & 5 & \\
\cline { 2 - 3 } & Marketing Personnel & 2 & \\
\hline
\end{tabular}




\begin{tabular}{|c|c|c|c|}
\hline \multirow[t]{4}{*}{ West FM } & Radio Managers & 1 & \multirow{4}{*}{12} \\
\hline & Technical Personnel & 4 & \\
\hline & Producers/Presenters & 5 & \\
\hline & Marketing Personnel & 2 & \\
\hline \multirow[t]{4}{*}{ Biikap Koret FM } & Radio Managers & 1 & \multirow{4}{*}{8} \\
\hline & Technical Personnel & 3 & \\
\hline & Producers/Presenters & 3 & \\
\hline & Marketing Personnel & 1 & \\
\hline \multirow[t]{4}{*}{ Radio Mukwano } & Radio Managers & 1 & \multirow{4}{*}{12} \\
\hline & Technical Personnel & 2 & \\
\hline & Producers/Presenters & 7 & \\
\hline & Marketing Personnel & 2 & \\
\hline TOTAL & & & 56 \\
\hline
\end{tabular}

\subsection{Data Collection Methods and Tools}

The main data collection methods used include questionnaires and interview schedules. Interviews were done face-to-face with the respective radio managers, presenters, producers and marketers. Orodho, (2005) describes a questionnaire as an instrument that gathers data and allows measurement for or against a particular new point. Quantitative data will be analyzed and presented descriptively and complemented by graphs, percentages and charts. Inferences will then be drawn from the findings. A report will be written in accordance to objectives of the study.

\section{RESULTS AND DISCUSSION}

Both descriptive and inferential statistics were adopted for this study. Descriptive Analysis of the Variables in the study included an assessment of how a competitive environment affects the sustainability of FM radio stations while being controlled by Political, Economic, Social, Technological, Environmental, and Legal factors. There were two sets of data collection tools. These included interview schedules for the five sample FM radio stations; tailored questionnaires meant for; marketing personnel, technical personnel, and producers/presenters. Apart from establishing the demographic characteristic of the respondent, each tool was designed to seek information that would aid in answering the research questions. The responses collected by each tool were collated qualitatively and quantitatively under themes. Descriptive statistics such as frequencies, percentages, means and deviations were used to describe the results.

\subsection{Response Rate}

Respondents who took part in the study were FM radio staff from; Nyota FM, Radio Mambo, West FM, Biikap Koret FM, and Radio Mukwano. The distribution of the data collection tools in each FM radio station is shown in Table Summary of Return rate per FM Radio Station below:-

Table3: Summary of Return rate per FM Radio Station

\begin{tabular}{|l|l|l|l|}
\hline FM radio Station & Total number administered & Filled and returned & \% frequency \\
\hline Nyota FM & 12 & 09 & 23.1 \\
\hline Radio Mambo & 12 & 09 & 23.1 \\
\hline West FM & 12 & 10 & 25.6 \\
\hline Biikap Koret FM & 8 & 04 & 10.3 \\
\hline Radio Mukwano & 12 & 07 & 17.9 \\
\hline TOTAL & 56 & 39 & 100 \\
\hline
\end{tabular}

A total of 56 questionnaires were administered to the sampled FM stations within Bungoma County. The questionnaires were then distributed to each department depending on the number of staff in each category. Out of the 56 that were administered (39) were returned having been filled thus giving a response rate of $69.6 \%$. This response rate, $(69.6 \%)$ was acceptable since it surpassed the minimal value of 50\% response rate prescribed for statistical analysis (Mugenda \& Mugenda, 2003).

Causal-Comparative study was conducted in the five FM Radio stations that were used in the study. As indicated above, a total of 39 participants responded in the entire sample population, which is a response rate of $69.6 \%$. West FM had the largest response rate of $25.6 \%$, while Radio Mambo and Nyota FM posted a $23.1 \%$ each, followed closely by Radio Mukwano with $17.9 \%$. The range among the response rates was obviously wider when it came to Mount Elgon based radio station, Biicap Koreet FM which had only $10.3 \%$. 
The low percentages were affected by operating capacity and minimal staff numbers within the radio stations which did not match the expected sample size. Most of these radio stations have staff doubling up as technical and production staff as well as marketing staff. Radio Mukwano and Biicap Koret FM are among the new radio stations with a small size of staff most of who are not employed on a permanent basis. Quite a number of these staff are on voluntary engagement and some are still students on an extended attachment thus requiring that in this research, we identify valid staff members only. This informed the low response rate from each radio station.

The researcher was also interested in knowing the return rate per category of participants. This information is shown below in Table 4.2 which summarises the return rate of the administered and filled questionnaires. These were then used in the analysis and presentation of results.

Table4: Distribution of response rate per category of participants

\begin{tabular}{|l|l|l|}
\hline Category of Respondents & Returned & \% frequency \\
\hline Radio Managers & 5 & 12.8 \\
\hline Marketing Personnel & 3 & 7.7 \\
\hline Technical Personnel & 6 & 15.4 \\
\hline Producers/Presenters & 25 & 64.1 \\
\hline TOTAL & 39 & 100 \\
\hline
\end{tabular}

In the research,(5) radio station managers were involved through an in depth interview to get insights on issues affecting sustainability of FM radio stations. A total of (3) marketing personnel participated across in filling the questionnaires while the technical personnel that participated were (6). Majority (25) of the participants in the study were producers who also doubled up as presenters.

\subsection{Responses by Producers/Presenters}

The following results were obtained from the questionnaires for Producers and presenters working in the radio stations. Their responses were organised thematically and presented as follows:-.

\subsubsection{Attendance of Refresher Trainings While Working in the Station}

When asked whether they have ever attended any trainings/short courses, the filed data indicated that $72 \%$ had attended various trainings. This is against a $28 \%$ minority who have not attended any capacity building trainings since they started working in their respective radio stations. This data is presented in Figure 4.3

\section{Attended refresher trainings}

$n=25$
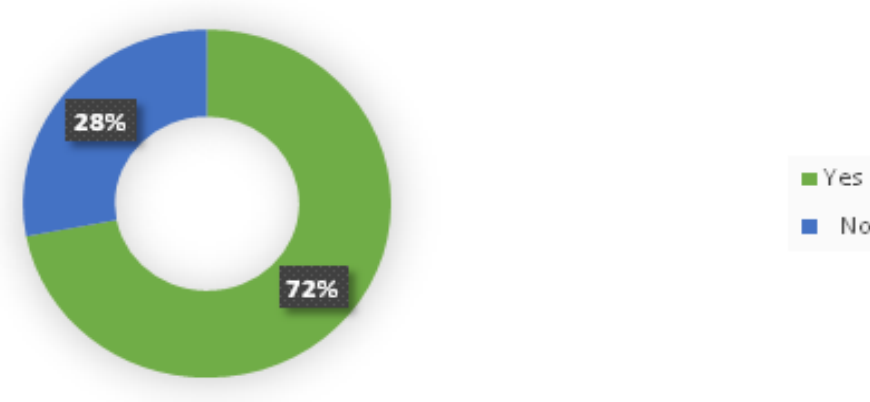

- No

Figure4: Response as to whether workers have undergone any refresher trainings while in the current FM Station

The participants indicated to have been trained on various topics such as human resource management, gender issues in media, child rights, reporting during elections, first aid, news writing and reporting, media house marketing, health, maternal and new-born reporting, renewable energy journalism, investigative journalism, reporting on devolution and presentation skills In the research findings, one of the organizations which has been partnering with the radio stations to offer capacity building training is Deutsche Welle (DW) Academia from Germany. This reveals that most of the radio stations have not initiated their own training programmes for their staff. 


\subsubsection{General factors affecting sustainability of FM radio Stations}

A four-point Likert ranking was used to assess the participants' level of agreement to social, environmental and economic factors that affect the sustainability of the FM radio stations in a competitive environment

\section{i) Social Factors}

The participants were asked to state their opinion on the following social factors that affect the sustainability of FM radio stations

Table5: Social Factors affecting sustainability of FM Radio stations in a competitive Environment

\begin{tabular}{|l|l|l|l|l|l|}
\hline Statement & SD & D & A & SA \\
\hline \multirow{2}{*}{ High staff turnover } & Count & 11 & 8 & 4 & 2 \\
\cline { 2 - 6 } & Percentage & $44 \%$ & $32 \%$ & $16 \%$ & $8 \%$ \\
\hline \multirow{2}{*}{ Use of temporary staff } & Count & 6 & 8 & 3 & 8 \\
\cline { 2 - 6 } & Percentage & $24 \%$ & $32 \%$ & $12 \%$ & $32 \%$ \\
\hline \multirow{2}{*}{ Under marketing } & Count & 7 & 10 & 8 & 0 \\
\cline { 2 - 6 } & Percentage & $28 \%$ & $40 \%$ & $32 \%$ & $0 \%$ \\
\hline $\begin{array}{l}\text { Little market share hence } \\
\text { revenues }\end{array}$ & Count & 6 & 3 & 12 & 5 \\
\cline { 2 - 6 } & Percentage & $24 \%$ & $12 \%$ & $48 \%$ & $20 \%$ \\
\hline
\end{tabular}

(SD-Strongly Disagree D-Disagree $\boldsymbol{U}$ - Undecided A-Agree $\boldsymbol{S A}$-Strongly Agree)

Table 4.6 outlines that $44 \%$ of the participants strongly disagreed that high staff turnover is a social factors affecting the sustainability of FM radio stations in Kenya. According to $32 \%$ of the presenters and producers, high staff turn-over is not a social factor affecting the sustainability of FM radio stations in a competitive environment. $16 \%$ were in agreement that high staff turn-over affects sustainability of FM stations while $8 \%$ strongly disagreed.

This is an indication that there is still a high staff turnover in the radio stations, however it does not in any way affect sustainability of these radio stations. Those who agree and those who strongly agree combined translates to $24 \%$ of the respondents and this is not a statistic to ignore. A good number of participants in the radio stations are in agreement that staff turnover affects sustainability of radio stations. This is informed by various reasons of presenter-listener attachment and varied approach to issues within programmes. Discontinuity or disruption of programmes along the way affects listenership and this negatively affects sponsorship and advertisement engagements as the core contributor to financial sustainability.

On the use of temporary staff in the FM station, 24\% strongly disagreed that this has a negative effect on sustainability of the station, while $32 \%$ recorded that using temporary staff is a social factor that affects the sustainability of FM stations in a competitive environment. 12\% agreed that the use of temporary staff contributes to sustainability of radio stations. This is somehow complemented by another $32 \%$ who strongly support the statement that using temporary staff is one of the social factors affecting how sustainable FM radio stations operate in a competitive environment. Temporary staff have a diverted attention with fear of unknown due to the uncertainty. Such staff dedicate their time to secure a permanent opportunity either with another entity or the same entity. This in turn affects productivity in these radio stations and thus affecting sustainability.

Under-marketing is strongly disregarded by $28 \%$ of the participants to be a factor that would affect FM stations' sustainability. This is highly supported by $40 \%$ who disagree as opposed to $32 \%$ who agree that undertaking marketing is a social factor that has a greater impact on the sustainability of the FM radio industry. However, power of marketing cannot be ignored. Marketing of segments and programmes is key for any radio station. This can be done through below the line or above the line strategy to attract listenership. Radio stations that do not engage in marketing programmes as a way of expanding their listenership usually remain with a predictable listenership scope thus enjoying an equilibrium status. They in turn limit active listenership because of their routine approaches and lack of creativity in programming. Such limitations immensely affect sustainability because majority of advertisers and sponsors buy the ears of the listeners.

Among those interviewed, $24 \%$ strongly disagreed that little market share by the FM radio station does not affect sustainability of the station, while $12 \%$ agreed to this statement, $48 \%$ agreed that 
having a little market share lowers revenues. Another $20 \%$ strongly agreed to this statement. This means that majority of the little market share is a social factor that impacts on the sustainability of these FM radio stations.

Radio stations in Bungoma County, Kenya enjoy almost the same limited spectrum allocation based on their operation licensing by the Communication Authority of Kenya (CAK). This in turn also limits their market share. The radio station compete for this market together with well-established and nation-wide radio stations. Such a congested market calls for stiff competition attracting a high charged strategy for sustainability.

Other social factors that were listed by the participants as those that affect the sustainability of FM radio stations in a competitive environment included the following:

- Lack or research when programming

- Less use of social media(New media) to engage the audience

- Little regard to the community through CSR initiatives

- Lack of professionally qualified personnel in running the station in key sectors such as marketing, and business development

- Little or no consideration of the content consumers when developing programs

- Absence of teamwork when adopting key policies that govern the FM station

ii) Environmental Factors

The study also required the respondents to rate their levels of agreement to the following statements. This was meant to find out the extent to which they agreed or disagreed that the following statements affected the sustainability of FM radio stations in Western Kenya.

Table6: Environmental factors affecting sustainability of FM radio stations in a competitive environment

\begin{tabular}{|l|l|l|l|l|l|}
\hline Statement & SD & D & A & SA \\
\hline \multirow{2}{*}{ Liberalized market environment } & Count & 4 & 2 & 11 & 8 \\
\cline { 2 - 6 } & Percentage & $16 \%$ & $8 \%$ & $44 \%$ & $32 \%$ \\
\hline \multirow{2}{*}{ Highly qualified radio presenters } & Count & 0 & 7 & 8 & 10 \\
\cline { 2 - 6 } & Percentage & $0 \%$ & $28 \%$ & $32 \%$ & $40 \%$ \\
\hline \multirow{2}{*}{ Lowly qualified radio human resource } & Count & 6 & 3 & 8 & 8 \\
\cline { 2 - 6 } & Percentage & $24 \%$ & $12 \%$ & $32 \%$ & $32 \%$ \\
\hline
\end{tabular}

(SD-Strongly Disagree D-Disagree $\boldsymbol{U}$ - Undecided A-Agree $\boldsymbol{S A}$-Strongly Agree)

From Table 4.6, it can be clearly seen that $16 \%$ of the respondents strongly disagreed that a liberalised market environment affects the sustainability of the FM radio station in a competitive environments compared to $8 \%$ who disagreed to this. A majority $44 \%$ were in the affirmation that liberalised market environment has an effect to performance of FM radio in terms of sustainability, while 32\% closely followed by strongly agreeing to the statement. From these responses, it can confidently be ascertained that the liberalization of the FM radio broadcasting space has a significant effect on the sustainability of FM radio stations in Kenya.

Engaging of highly qualified radio presenters as an environmental factor had no participant in the study that strongly disagree. It was interesting to see the steady progression sequence on how participants responded to this statement. While $28 \%$ of them disagreed, $32 \%$ agreed that an FM station with highly qualified staff has an effect on the sustainability of the station. An overwhelming $40 \%$ strongly agreed that an FM radio station with highly qualified staff is a positive factor that contributes to sustainability of FM radio stations in a competitive environment, this is compounded by production of quality programmes.

In this research findings, touching on less qualified radio human resource, 24 percent strongly disagreed that FM Radio having less qualified staff may not affect sustainability. There was 32 percent of the respondents who disagreed while 32 percent agreed that it has an effect on the sustainability of the FM station. Similarly, 32 percent were of the strong opinion that FM Radio 
stations with less qualified human resource affects the sustainability of FM radio stations in a competitive environment.

During the interviews with Radio producers and presenters, they were asked to mention any other environment related factors that impact on the performance of FM radio in Kenya, dominating factors in the discussions included:-

- Stiff competition from well-established media:

- Use of unsuitable/unqualified staff in running radio programming

- Poaching of good and talented staff by established and upcoming radio stations:

- Lack of modern equipment to match the current broadcasting trends:

- Lack of motivation programs for staff

\subsection{Economic Factors}

This study further sought to investigate the respondents" level of agreement to a list of statements that described the extent to which the sustainability of FM radio is affected in a competitive environment. Their responses are summarised in the following table.

Table7: Economic factors affecting sustainability of FM Radio stations in a competitive environment

\begin{tabular}{|c|c|c|c|c|c|}
\hline \multicolumn{2}{|l|}{ Statement } & SD & $\mathrm{D}$ & $\mathrm{A}$ & $\mathrm{SA}$ \\
\hline \multirow{2}{*}{ Workforce's demand for higher pay } & Count & 2 & 1 & 10 & 12 \\
\hline & Percentage & $8 \%$ & $4 \%$ & $40 \%$ & $48 \%$ \\
\hline \multirow[t]{2}{*}{ High cost of living } & Count & 1 & 6 & 11 & 7 \\
\hline & Percentage & $4 \%$ & $24 \%$ & $44 \%$ & $28 \%$ \\
\hline \multirow[t]{2}{*}{ High cost of doing business } & Count & 0 & 2 & 7 & 16 \\
\hline & Percentage & $0 \%$ & $8 \%$ & $28 \%$ & $64 \%$ \\
\hline \multirow{2}{*}{$\begin{array}{l}\text { Unrealistic expectations about the Media } \\
\text { fraternity }\end{array}$} & Count & 4 & 9 & 3 & 9 \\
\hline & Percentage & $16 \%$ & $36 \%$ & $12 \%$ & $36 \%$ \\
\hline \multirow{2}{*}{$\begin{array}{l}\text { Lack of knowledge on resource } \\
\text { management }\end{array}$} & Count & 3 & 1 & 16 & 5 \\
\hline & Percentage & $12 \%$ & $4 \%$ & $64 \%$ & $20 \%$ \\
\hline \multirow{2}{*}{$\begin{array}{l}\text { Inadequate financial resources to } \\
\text { support the radio stations }\end{array}$} & Count & 0 & 2 & 4 & 19 \\
\hline & Percentage & $0 \%$ & $8 \%$ & $16 \%$ & $76 \%$ \\
\hline \multirow{2}{*}{$\begin{array}{l}\text { Unhealthy competition from emerging } \\
\text { radio stations }\end{array}$} & Count & 5 & 2 & 10 & 8 \\
\hline & Percentage & $20 \%$ & $8 \%$ & $40 \%$ & $32 \%$ \\
\hline
\end{tabular}

(SD-Strongly Disagree D-Disagree $\boldsymbol{U}$ - Undecided A-Agree SA-Strongly Agree)

Table 4.8 indicates that majority (48\%) of the respondents strongly agree that workforce's demand for higher pay affects the sustainability of an FM radio station in a competitive environment. This means that a station with employees that are undergoing financial starvation are more likely to be less productive and therefore vulnerable to a competitor who pays more or promises to pay the staff more if they joined them. It is therefore a risk to the FM Radio industry which eventually has a negative effect to the sustainability of such affected radio stations. This will resort to fresh recruitment or even struggle to attract competent human resource.

More related, $40 \%$ of the FM radio presenters agreed that a work force's demand for higher pay has the potential to affect the operations of the radio station. Only $4 \%$ representing one respondent disagreed to this statement, while the rest $(8 \%)$ of the respondents strongly disagreed that the sustainability of FM radio stations in a competitive environment can be affected by demands for higher pay by workers in the FM radio stations.

The cost of doing business is cascaded down to that of production of programmes and in view of this, there was a $64 \%$ of the participants who were of the strong opinion that high cost of doing business affects the sustainability of FM radio stations amid a highly competitive surrounding. $28 \%$ agreed to the statement that high cost of conducting business in the country affects radio's operations.

Apparently, when it came to the lack of knowledge on resource management, $12 \%$ strongly disagreed in the same way another $4 \%$ disagreed that is affects FM radio's operations in a competitive 
environment. However, there was a major $64 \%$ of the participants who agreed that FM station's staff without resource management knowledge can affect sustainability. The participating media houses indicated through a 20\% response that sustainability of the FM radio station can be compromised if there is a lack of knowledge on resource management. Prudent use of resources especially in well researched programmes will add value in sustainability of Small FM Radio stations in Bungoma County, Kenya.

A commendable $76 \%$ of the respondents were of the strong opinion that inadequate financial resources to support the radio stations can affect their sustainability. Their response is followed by $16 \%$ who agree to the statement that inadequate financial resources to support the radio stations is an economic factor that has a bearing on the sustainability of FM radio, while 8\% disagreed that radio stations with inadequate financial resources affect their sustainability. This is a clear indication that financial resources play a critical role in sustain FM radio stations.

iii) Political factors affecting programming in FM radio stations

The study established the following factors that affect programming and in turn the sustainability of FM radio stations:-

- Influence of political class in the media industry by demanding coverage in their events with the promise of unspecified consequences if the FM stations fails to give them airtime. This impacts negatively on content production and listeners opinion.

- The need by some media houses to align themselves to some political figures and take a specific political stand to serve their interests thus affecting objectivity.

- Political patronage_ which interferes with the societal perspective of the independence the concerned FM radio stations

- Radio ownership by political class, who strategically put up the radio to serve political interests at the expense of quality programming.

iv) Legal factors affecting the sustainability of FM radio stations in Kenya

- Delays in awarding broadcasting licences to emerging radio station

- Bureaucracies in registering upcoming radio stations

- Unfavourable policies that limit media freedom

- Duplication of other station's programming without consent of the originators. This leads to legal battles that may end up in payment of fines and litigation fees. These eat up into the revenues of the FM radio station.

- Unfavourable government regulations regarding advertising

- Defamation litigations

- Forced government regulations such as the recent digital migration that was initiated by the regulator $(\mathrm{CAK})$ that led $\mathrm{t}$ the closure of some stations due to non-compliance.

- Poor programming; more so use of vulgar language and explicit content on radio (especially morning/breakfast shows). This leads to suspensions and penalties to the affected stations, an act that destabilises the growth of the FM radio station in Kenya.

- High licensing fees charged by the CAK

\subsection{Responses from the Technical Crew}

The researcher was able to capture the views of six (6) technical crew personnel from the sample FM radio stations. The study sough to establish where the respondents (technical crew) thought that technology plays any significant role in the sustainability of FM radio stations in Western Kenya. 


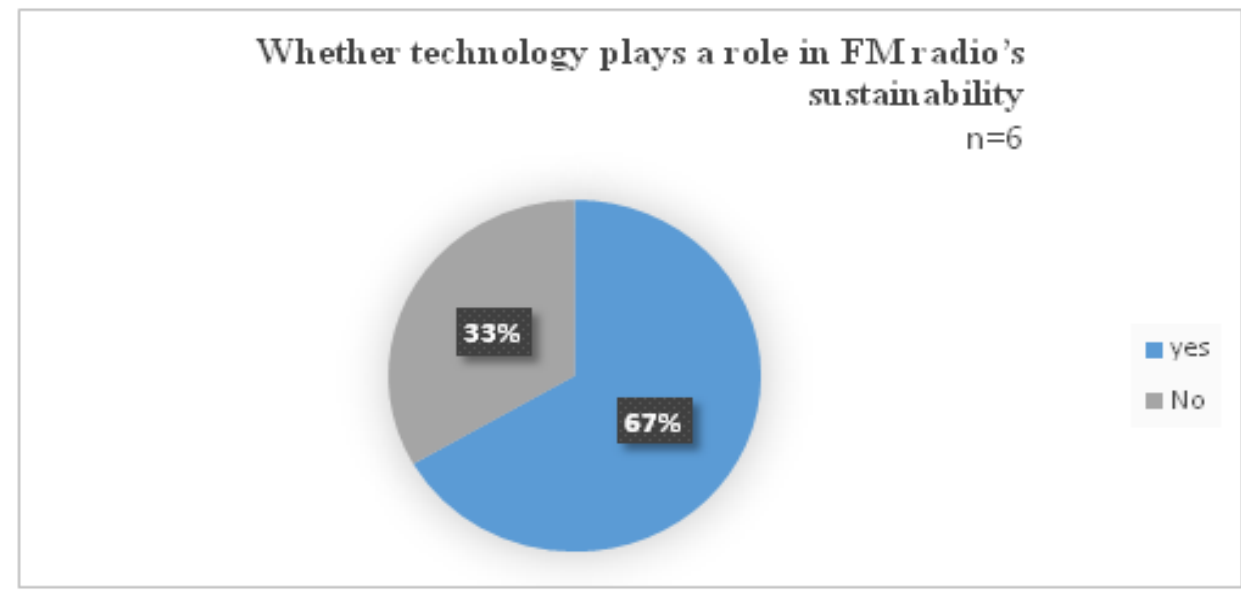

Figure5: Whether technology plays a role in the sustainability of FM Radio stations in a competitive environment

The data analysis revealed that $67 \%$ of the respondents, who were also the majority, indicated that technology plays a significant role in the sustainability of FM radio stations in the select FM radio stations. However, another $33 \%$ were of the negated by indicating that technology does not play a role in FM radio's sustainability.

One of the respondents reported that technology plays a role in conducting research on how to improve programming and content development. That technology provides a highway for searching, verifying, comparing and validating data that would be used to come up with competitive radio content in additional, Respondents agree that content collection in radio is fundamental to giving comparison and enriching productions. They believe that with good equipment containing robust storage capacity and compression capacity will enhance collection and archiving of content level of Influence of variables on the sustainability of FM radio stations

In this section, participants were required to indicate their level of agreement on a five-point Likert scale. They were required to show this by marking SD- Strongly Disagree, D-Disagree, UUndecided, A- Agree, and SA-Strongly Agree basis. Their responses were collated and summarised in table 4.9 below.

Table8: Level of influence of variables on sustainability of FM Radio stations in a liberalized market

\begin{tabular}{|l|l|l|l|l|l|}
\hline Statement & SD & D & U & A & SA \\
\hline Use of modern and updated production software & 0 & 0 & 0 & 3 & 3 \\
\hline Use of modern production equipment in the studio & 0 & 0 & 0 & 3 & 3 \\
\hline Integration of technology in broadcasting & 0 & 0 & 0 & 3 & 3 \\
\hline Research and production of human oriented content & 0 & 0 & 1 & 1 & 4 \\
\hline Radio programs and programming & 0 & 0 & 0 & 3 & 3 \\
\hline Use of social media to reach out to more audience & 1 & 0 & 0 & 1 & 4 \\
\hline
\end{tabular}

(SD-Strongly Disagree D-Disagree $\boldsymbol{U}$ - Undecided A-Agree SA-Strongly Agree)

From Table 4.9, there were as many technical crew personnel who agreed as there were who those who strongly agreed that using modern and updated production software's influences the sustainability of FM radio stations. The same result was recorded on the influence of modern production equipment in the studio. Reponses from filed data further indicated that integration of technology in broadcasting has the ability to influence the sustainability of FM radio in a liberalised market. On this statement, both those who agreed and those who strongly agreed posted a positive response, which was a strong implication that FM stations that embrace technology has higher chances of staying in business in a liberal market.

It is in the opinion of a many technical personnel that radio programs and programming can influence sustainability of FM radio in a free market. However, when it came on the influence of social media to reach out to more audience, the responses were as follows:-

One participants strongly disagreed to this, while four out of the maximum six strongly agreed to the statement that use of social media to propel programmes and radio agenda to more audiences has an 
impact on FM radios sustainability. The agreement by another one to this is a conviction majority of the participants believe in the effect of social media towards building the FM radio's existence in a free market like that in Bungoma County, Kenya.

\subsection{Equipment Capacity for Production and Transmission of Radio Programmes}

The study established the equipment capacity of the radio stations according to the uses of each. This research chose to investigate the presence or absence of various basic instruments, machines, equipment that are necessary for the ruining of an FM radio station as follows.

Table9: Adequacy of machines and equipment

\begin{tabular}{|l|l|l|}
\hline Question & Yes & No \\
\hline Is your audio recording and editing equipment enough for all your productions? & 4 & 2 \\
\hline Is your radio stations data storage capacity enough & 5 & 1 \\
\hline Do you have a reliable power back up system? & 3 & 3 \\
\hline Do you sometimes go off air? & 1 & 5 \\
\hline Do you have a Back-pass Filter for signal stability and restriction? & 5 & 1 \\
\hline Do you have installed transmission delaying machine/Gadget in aid of real-time censorship? & 5 & 1 \\
\hline Is your live broadcast archived on real time? & 5 & 1 \\
\hline Is your live studio fit with a professional broadcast console? & 4 & 2 \\
\hline Total & 32 & 16 \\
\hline Average Mean & 4.0 & 2.0 \\
\hline
\end{tabular}

Table 4.11 indicates that majority of the radio stations had enough recording and editing equipment while another super majority agreed that their station's data storage capacity was enough. Among the six FM radio stations that participated in the study, there was a balance between the stations that reported to be having reliable power back up systems. As if to proof that the power back up systems were reliable, only one radio station reported to be sometimes going off air due to power outages. For signal stability and restriction gadget installation, five (5) out of six (6) agreed to be having these gadgets in the radio station. In a similar way, five of the six FM radio stations agreed to be have installed transmission delaying gadgets that aids of real-time censorship. The study also found out that majority of the FM radio stations had their broadcasting archived as soon the content is broadcasted. When it came to the question of having professional broadcast consoles in the FM radio stations, four of the six claimed to be having the standard console machines.

\subsection{Challenges FM Radio Stations Face in a Competitive Environment}

The study sought to find out the challenges that are faced in production of various programs which impact on sustainability of FM Radio stations. The technical crew who double up as producers mentions the following challenges.

- Inadequate recording equipment to serve the many reporters as well as stringers in the field. This means that in case there is need to have many reporters in the field, the available recorders won't be enough to serve the purpose. This compromises quality because at times, the journalists are forced to use gadgets like their mobile phones in taking audio sound bites which may not be able to give quality recordings.

- Time constraints in preparing broadcast content: Due to lack of enough personnel in this radio stations, the available few are overwhelmed by load of work and therefore don't meet datelines. Some of them are forced to abandon project on the way and this compromises quality.

- Limited audio editing equipment: It was noted that each Radio stations in Bungoma County Kenya, has only one audio editing suit or studio. This make it difficult for different radio projects to be worked on at the same time. Beside, in case of any technical hitches, there are delays in production which affects the entire departments of the radio stations.

- Outdated audio editing software: These radio stations have outdated software's in that they are rarely upgraded. It was noted that most of these software's are patched software's or free downloadable software's with minimal functionality, therefore not able to maximise their use.

- Inadequate and unreliable data storage facilities: Radio stations produce massive data on a daily basis and this require enough storage capacity to store/archive data. Most of the radio stations 
visited during this research only depended on internal hard disks for data storage. This is a high risk especially when the computers are dysfunctional. It is also possible to lose all the data when the archive source is one and constrained through daily accessibility and routine running of the radio station programmes.

\subsection{Pertinent Issues about the Operations of the FM Station}

This section compiled a list of questions that required the manger to give Yes or No answers. Their responses were collected and tabulated accordingly as shown below.

Table10: Pertinent issues on the operations of the FM Radio stations

\begin{tabular}{|l|l|l|l|}
\hline \multicolumn{2}{|l|}{ Table 10. Pertinent issues on the operations of the FM Radio stations } & Yes & No \\
\hline S/No & Question & 2 & 3 \\
\hline 6 & Can you say that the radio station made profits in the last finacial year? & 3 & 2 \\
\hline $6(b)$ & Was the organization able to sustain its daily operations? & 4 & 1 \\
\hline 7 & Do you have employment equity procedures? & 5 & 0 \\
\hline 8 & Do you carry out entry auditions for radio presenters? & 4 & 1 \\
\hline 10 & Do you have volunteers working in your radio station? & 0 & 5 \\
\hline 11 & Do you have a volunteer policy document/ guides? & 5 & 0 \\
\hline 12 & Have you developed a clear job description for staff? & 5 & 0 \\
\hline 13 & Do you offer any needs-based training to your staff? & 4 & 1 \\
\hline $13(b)$ & Does needs-based training contribute to staff retention at your radio station? & 2 & 3 \\
\hline 14 & Do you have an employee motivation program? & \\
\hline
\end{tabular}

Out of the five radio station that took part in the survey, only 2 made profits. In the same breadth, 3 of them were able to sustain their daily activities while 2 did not due to resource constraints. It was worth to note that all the radio stations subjected their candidates to entry auditions during recruitment however one out of the five FM radio stations does not have an employment equity document. Most of the FM radio stations in the study reported to be having volunteers amongst their human resource, however, none of the FM radio stations have a laid out policy document specifically for volunteers.

For voluntarism to be effective there is need for the community to be educated about voluntarism and to understand why volunteers are not paid. Since there is a mix of people doing voluntary work including professionals, students and unemployed people, community stations should hold auditions for new volunteers based on clear criteria that is compatible with station's policies (Open Society Foundation; Volunteers: Pavlicevic,1999)

\section{CONCLUSION}

The primary goal of this study was to identify causes of sustainability challenges in Local FM Radio stations and remedies that would ensure smooth operations. The findings of the study revealed that motivation, adequate facilitation and training of staff, coupled with creation of quality educative and informative content by FM radio stations based on current audience research data or survey, will enhance sustainability of these FM radio stations operating in Bungoma County, Kenya.

\section{RECOMMENDATIONS}

This study found out that the FM radio stations are experiencing a number of challenges in their daily operations. Some of these include inadequate recording equipment, time constraints in preparing broadcast content, limited audio editing equipment, outdated audio editing software, inadequate and unreliable data storage facilities for production. The study therefore recommends as follows:

1. Radio stations in Bungoma County should invest in research especially in the development of educative and informative programmes that would attract advertisers and sponsors.

2. They must consider recruiting more skilled and qualified staff especially in critical departments like production, marketing, broadcast, reporting and branding

3. Fm Radio stations in Bungoma County must defined their target audience with a keen analysis of the same, to ensure that the content created is specifically meeting their needs

4. Local FM Radio stations should encourage frequent capacity building for the management of FM Radio stations and other in-house trainings to staff as a way of empowering them with knowledge on trending issues. 
5. Radio Stations must embrace new technology such as social media, online broadcasting and integration of emerging technological platforms in radio programme production to enhance coverage.

6. FM radio stations should embrace collaboration with other radio stations in content sharing to provide variety and widen listenership.

7. FM Radio stations in Bungoma County should adequately remunerate and facilitate radio staff to be able to produce quality programmes.

\section{REFERENCES}

[1] Bosch, T. E. 2007. Sustaining Community Radio. UNESCO Community Radio South Africa. http://www. i4donline.net/articles/currentarticle.asp?articleid=1156\&typ=Features. Accessed: 29th June 2007.

[2] Bosibori, O.C. (2011). Challenges in Setting up And Operating a Community Radio Station in Kenya: Study of Community Radio Stations in Nairobi. MA Thesis. University Of Nairobi.

[3] Creswell, J. W., (2009). Research Design. Qualitative, Quantitative and Mixed Methods Approaches. Sage Publications. Thousand Oaks, Calif.

[4] Githaiga, G.,Technological Advancement: New Frontiers For Kenya's Media?.The Immediate Former President of The African Chapter Of The World Association Of Community Broadcasters (AMARC), And A Former Director of Econews Africa.

[5] Gumucio-Dagron, A. (2001). Art of Aerialists: Sustainability of Community Media. New York: Rockerfeller Foundation

[6] Kijana, E., (2012). "A General Assessment of the Independent Ethnic Radio Broadcasting Stations in Kenya."International Journal of Business and Social Science Vol. 3 No. 8 [Special Issue - April 2012] 128

[7] Kijana, E. (2012). A General Assessment of the Independent Ethnic Radio Broadcasting Stations in Kenya. International Journal of Business and Social Science Vol. 3 No. 8 [Special Issue - April 2012] 128

[8] Mcanany, E. (Ed.) (1980). Communications in the Rural Third World. Praeger.

[9] Mudhai, O. F. (2011). Survival of 'radio culture 'in a converged networked new media environment. Popular media, democracy and development in Africa, 253-68.

[10] Mugenda, A. G. (2013). Qualitative research methods

[11] Myers, M. (2011). Voices from Villages. Community Radio in the Developing World. A report to the Center for International Media Assistance. 5 April 2011.

[12] Open Society Foundation; Volunteers: Pavlicevic, 1999

[13] Saidou, D. (2002). Radio Broadcasting and New Information and Communication Technologies: Uses, Challenges and Prospects. United Nations Research Institute for Social Development (UNRISD). Geneva. Switzerland.

Citation: Jared M. Mudanya, Dr. Peres Wenje. "Assessment of Sustainability Challenges of FM Radio Stations in Bungoma County, Kenya ". International Journal of Media, Journalism and Mass Communications (IJMJMC), vol 5, no. 3, 2019, pp. 25-36 doi: http://dx.doi.org/10.20431/2455-0043.0503003

Copyright: (1) 2019 Authors. This is an open-access article distributed under the terms of the Creative Commons Attribution License, which permits unrestricted use, distribution, and reproduction in any medium, provided the original author and source are credited. 